\title{
MEDIEVAL GRAVE FRESCOES IN THE SOUTHERN NETHERLANDS AND BRUGGE
}

\author{
C. L. Williams \\ Roosevelt Academy Middelburg: P.O. Box 94, NL 4330AB Middelburg, The Netherlands
}

KEYWORDS:Medieval, frescoes, graves, Middelburg, Brugge, Aardenburg, Conservation, SCEZ, Raakvlak.

\begin{abstract}
:
Written to accompany a longer study, this short paper firstly highlights the uniqueness of medieval grave wall paintings in the south of The Netherlands and Brugge, Belgium; and secondly suggests mostly preventative conservation methods to aid the ongoing protection of these frescoes. Though graves are scattered, this study focuses on graves from three nearby but very different locations, Brugge, Aardenburg, and Middelburg. Graves share stylistic and motif similarities that result in the need for scholars to group these graves together as a type, in a way that was not done previously, as one by one the graves were accidentally found since the $1950 \mathrm{~s}$. Despite how these graves have been subjected to drastically different environments in previous decades, the problem of their conservation needs to be addressed using co-operation between the various regions rather than individually. The Saint Salvator Church in Brugge has already taken action recently, securing protection for the four painted graves with regulated air-conditioning under air-tight glass floor displays. The time is right to encourage appropriate action for other comparable graves nearby.
\end{abstract}

\section{GRAVES IN BRUGGE, AARDENBURG AND MIDDELBURG}

\subsection{Introduction}

Scattered over the south of The Netherlands and in Brugge, Belgium, are a number of medieval graves covered in wall frescoes. There is the odd grave in France and Germany, but otherwise these graves are unique to the region. Despite similar stylistic motifs and subject matter, until now they have rarely been considered as a group, and each local area handled itself independently. Fortunately many locations with graves are in Zeeland, putting them under the care of Stichting Cultureel Erfgoed Zeeland (SCEZ). To date, there are no known groups of graves with frescoes with which to compare those discussed in this paper. This paper encourages co-operation for the preservation of this local heritage to help with optimizing the methods of documentation and conservation. Each area has survived different environments which influence how they must be handled from here onwards. Firstly, a short description of medieval grave paintings is given, explaining what makes them unique. Then, an interpretation of the graves history and design brings them together as a group. Afterwards, an analysis of the graves condition will lead to a practical argument about how to stabilize and then treat and preserve these pieces of Dutch and Belgian heritage. This paper has been written at a critical time shortly after successful cleaning and display of grave frescoes in Brugge. The city was the epicentre of the grave origins, and today it could be the leading example of how to care for the rest of the graves in the surrounding region.

\subsection{Medieval Grave Frescoes}

Frescoed grave paintings are both unique and challenging to conserve, and there is a definitive lack of sources focusing on the unique problems they bring. It is crucial to distinguish how sources on general wall paintings or frescoes cannot necessarily be applied to grave paintings.
Graves do not hold the architectural significance of many wall paintings located on roofs or weight bearing walls. As a result, grave paintings are considerably more transportable and are often relocated. Often paintings will consist of mineral pigments painted over plaster and mortar, covering thin red brick walls. It is hard to assume styles of wall paintings coincide with graves, so dating is difficult. This is because graves are not meant to be seen, they are part of the medieval burial ritual. The dead needed to be buried within 48 hours of death leaving little time for painting to be completed (Information boards St Salvator Church, 2011). Interpretation of grave paintings must keep in mind their predominant role as part of medieval burial rituals. At their core, grave paintings, like general wall paintings share common physical threats of deterioration after excavation. They suffer from light, temperature, humidity, vandalism, poor prior treatments, flaking and so on. It is important to refer to literature on wall painting but with a close eye to ensure the appropriate circumstances are considered.

\subsection{Historical Context}

\section{BRUGGE}

Of all the cities that house grave frescoes, Brugge is the largest with 16 grave locations (Information boards St Salvator Church, 2011). It was likely the centre of this medieval practice due to its role in communication with surrounding areas. Further locations are known in Zeeland, Utrecht, South-Holland, North-Holland, North Brabant, Gelderland and a few in Germany and France. Almost nothing is known about how and why this practice spread to these regions. After excavations between February and May 2011, Brugge has the most recent information, and most effective display methods [Fig. 1]. 


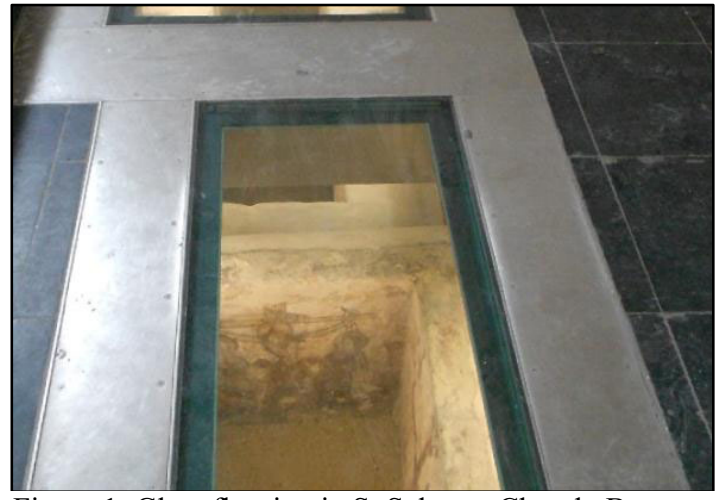

Figure 1: Glass flooring in St Salvator Church, Brugge.

However, the graves were discovered during 1989-1993 excavations, approximately the same time Haakma studied the Aardenburg St Bavo Church grave paintings, published in 1994. Before recent excavations and display in Brugge's Sint Salvator Church, Haakma was the last to seriously study grave frescoes in the region.

The St Salvator church is filled with almost countless graves, but only four have frescoes. The four graves are permanently excavated, and are prepared for mass public viewing. The graves' walls are clean, often with a layer of new cement along the top of the walls for stability. The human remains are still under the layer of sand. They are still underground at their original depth, with a glass layer added above which can be walked on. Underneath the glass, light makes the graves visible. Results presented to the public via A0 posters in 2011/2012 in the church provided interesting interpretations of the grave fresco imagery. Due to the Franciscan influence the imagery is linked back to the name of the church. Christ is argued to be presented as the suffering Christ, and when with the globe, as Salvator Mundi - the blessing Christ [Fig. 2].

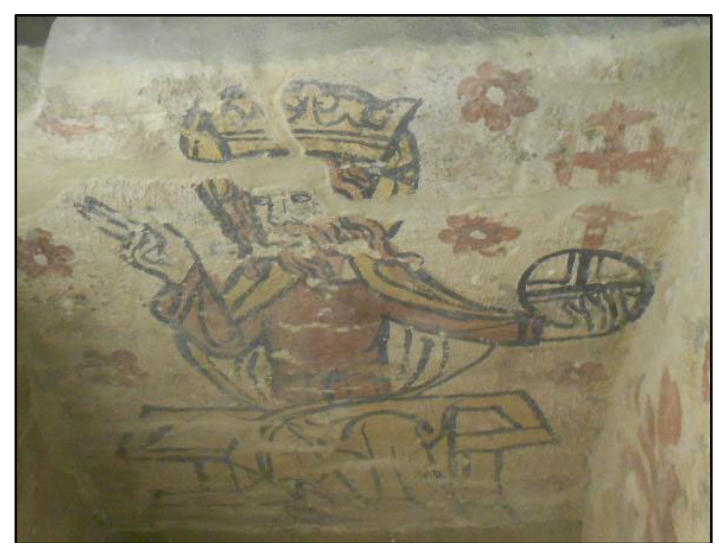

Figure 2: Blessed Christ, St Salvator Church, Brugge.

Mary is seen as the queen and mother or advocate nostra the advocator and mediator in heaven who pleads the salvation of the dead [Fig. 3] (Information boards St Salvator Church, 2011). This is interesting, but only analyses the graves within the context of the church.

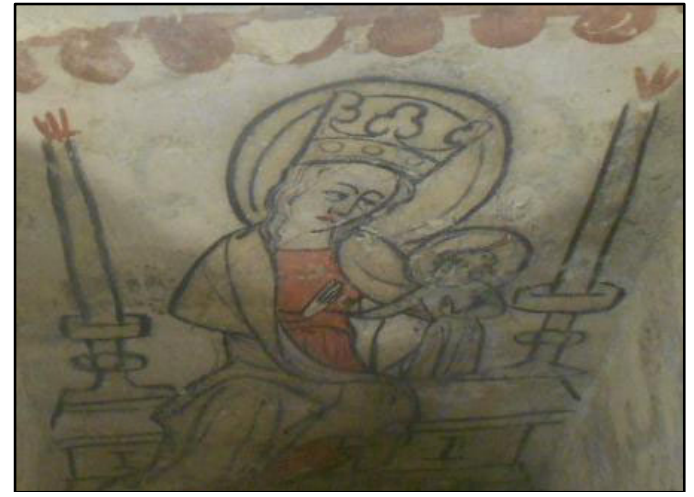

Figure 3: Throning Madonna with Child, St Salvator Church, Brugge.

In Brugge it is interesting that design motifs are not consistent. Angels will often be used as examples for this study because they are prevalent in all three locations. For example there is the pattern on long grave sides of depicting angels swinging incense burners, but in Brugge there are definite differences between graves. The first type is stiff, with heavy material clothes coloured in bands with black outlines. Wings are bold, with simple feather patterns created through the outline, and they are quite symmetrical. The second type is much less stiff looking. Bodies, arms and faces are twisted; along with the clothing they convey movement. The wings are far simpler. They are merely flowing black lines. Graves contain similar motifs such as small flowers, crosses, and a red repetitive border along the top. What is seen in Brugge is a consistency in topic, but not style. There is currently no certain explanation for this.

\section{AARDENBURG}

Through its proximity to Brugge, Aardenburg grew to be one of the biggest cities in Zeeuws-Vlaanderen. The St Bavo Church suffered extensive damage in October and November 1944 of the Second World War, which took a decade to repair (Hutsebaut, Dhont, and Aerts, 2010). It was during these repairs, that the first of twenty grave paintings were discovered on March $3^{\text {rd }} 1948$ by restaurator P. Postma. (Haakma, 1994). Since then, there have been additional excavations to explore the church's architectural history in 1952, 1955 and 1956 (Renaud, 1956; Devliegher, 1956). Restoration of the St Bavo Church was from 1947-1956 (Devliegher, 1956). The date the grave frescoes were painted is still debated. Dezutter agrees that the estimated date by Devlieger of approximately 1330 can be plausible (Dezutter, 1970). Although there have been other graves with paintings discovered in the immediate area, for example in Sluis, and Brugge, the Sint Bavo Church in Aardenburg contains the most, 20 complete graves, and two additional parts of other graves with medieval wall paintings. Today ten of the graves remain excavated, and have been lifted out of the ground, but are still above the same location. The rest have been filled in again after excavation and documentation were completed.

Art Historian and Archaeologist Dezutter completed an entire iconographical interpretation of every painting from 1969 to 1970 for his PhD. Although his descriptions were centred on Aardenburg, Dezutter included short introductions to other graves in Zeeuws-Vlaanderen indicating that he considered the painted graves of the region to be connected. Unfortunately the photo albums that accompanied his thesis are no longer to be found. However, the images by s 'Jacobs, 
show some characteristics that were also present in Brugge's Saint Salvador church (s 'Jacobs, 1955). Angels are often, but not always painted on the long sides of graves with varying degrees of similarity in the shape of the wings and halos. Smaller andreas crosses and larger lily crosses are painted, as well as plants containing the lily motif. Madonna and child, who is often throned, as well as Calvary scenes and the suffering cross are still common scenes for the short ends of the graves. However, there is no blessing Christ to be found. This is one feature that tied the Brugge interpretation to the name of the church itself. The painting style is variable much like those in Brugge.

\section{MIDDELBURG}

Middelburg is the capital city of the Province of Zeeland and the home of Stichting Cultureel Erfgoed Zeeland (SCEZ). The nine grave paintings in a crypt underneath the Abdijplein of Middelburg are crucially different from those in Brugge or Aardenburg because they have been relocated from their original burial place, and most have lost the context that comes with this. The paintings are presented as follows: one whole grave with four walls painted [Fig. 4], two short ends of a grave framed side by side [Fig. $5 \& 6$ ], and three long sides of unknown graves [Fig. 7].

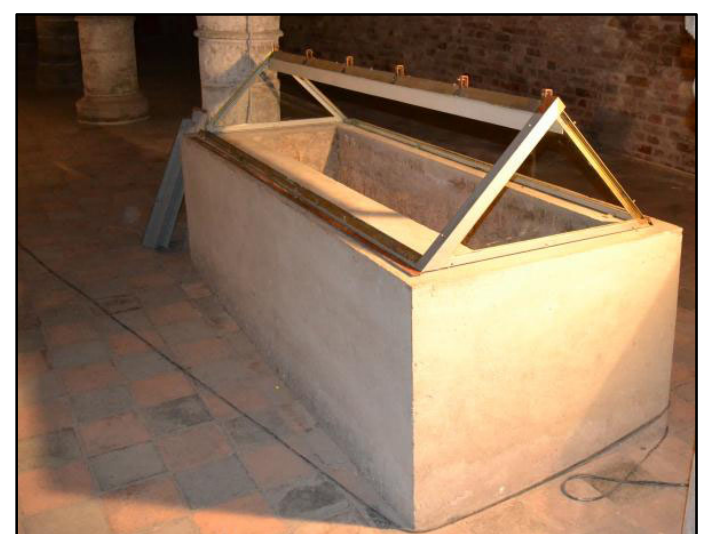

Figure 4: Grave 2307-1 with glass casing, Middelburg.

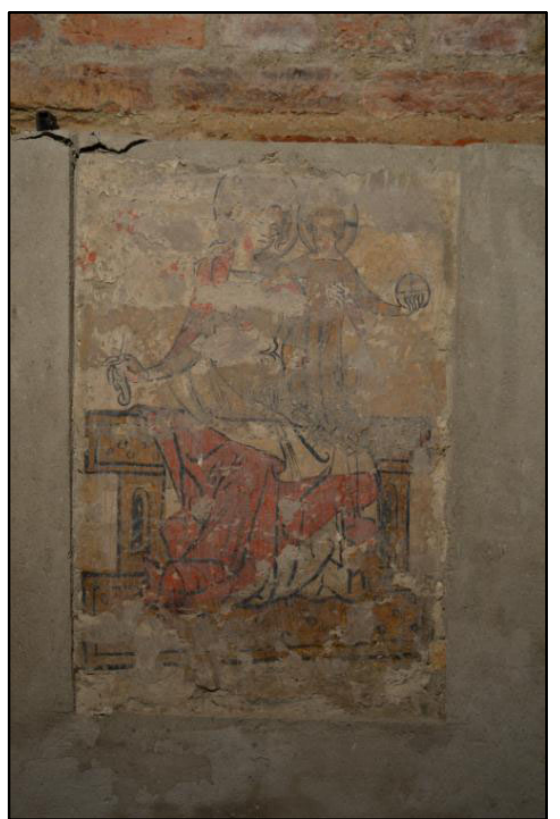

Figure 5: Fragment 2307-2a without casing, Middelburg.

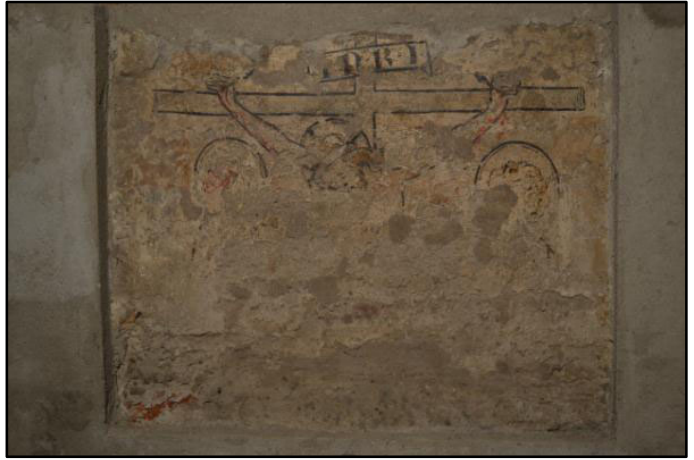

Figure 6: Grave fresco 2307-2b without casing, Middelburg.

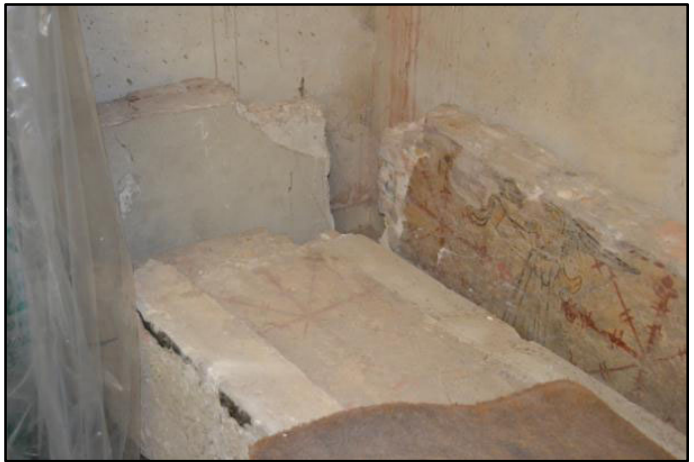

Figure 7: Grave walls 2307-3,4\&5, Middelburg

These paintings have recently received attention when SCEZ conducted a preliminary documentation of what condition they were in during April 2011. The documentation process was part of a larger study that included an attempt to trace the history of each painting, with some success. Two short ends of graves have been linked through literature and visual images to the 1947 excavation in Sluis.

Discounting the one inaccessible long side of a grave which faces the wall, visually the Middelburg graves are much more consistent in style than either Brugge or Aardenburg. Four visible long grave sides all contain angels swinging incense burners. There are aspects present in all three locations to some degree. For instance, colours are filled in without gradation, the shape being created by thick black outlines. Spaces are filled with large Andreas and Lily Crosses, and identical red borders along the top edge of graves. Motifs like the border, crosses, and small flowers are generally consistent at each location; it is the angels which change drastically in style in Brugge and Aardenburg. In Middelburg the flowers are less prevalent due to a generally fuller design, but they are also less shapely, those in Brugge having a six petal shape with a white center. Consistently as with Brugge and Aardenburg, the short grave ends in Middelburg share common themes. In this case the four short ends are made of two Madonna and Child depictions, one crucifixion and one Calvary scene. Once again there is no blessing Christ, this is so far found only in Brugge, giving weight to the interpretation that it is linked to the name of the church itself. It is indicated that Madonna and Child is a theme for almost every grave of this sort no matter the location, while the second end could have various options. After three comparisons it is evident that there are similarities and differences between the three locations. Most importantly however is the consistency of subject matter, painted onto the walls of graves built into the floor of large city churches in medieval times. 


\subsection{Conclusion}

Aesthetic patterns and similarities link these graves together, but there is more they have in common. Behind the painted surface, the grave walls are primed with mortar and plaster on brick indicating the graves were prepared in a similar manner. As is the case with the Sintsalvatorkerk in Brugge, it is likely most others were also prepared hurriedly within 48 hours of the death. The Aardenburg graves are tentatively dated to 1330 , and the others are even less certain. Nonetheless, although the $14^{\text {th }}$ century was an unsettled one for the area, Aardenburg and Middelburg were never strangers with Brugge meaning they had constant contact with one another. Dezutter, the writer of the Aardenburg graves demonstrated in 1970 that the local grave paintings were associated with each other by describing them in his thesis, but unfortunately today the sites are still much more individual than they are a group.

It would be very beneficial for each grave site to embrace its place within this uniquely limited interregional phenomenon. Some change would be necessary. No longer would decisions be made considering only the immediate graves and surroundings in each city; local authorities from Middelburg, Aardenburg, Brugge and other minor locations would need to work with SCEZ and Raakvlak (Archaeology Service for Brugge and Ommeland) which would be challenging to implement. However, when these graves are treated together as a type much more can be achieved. Information can be exchanged, for example about display effectiveness, treatment results, deterioration, information found in one location. It is not the purpose of this paper to promote tourism but it must be acknowledged that it holds great potential. Brugge has already acknowledged the presence of visitor interest by putting up excavation posters and a visitor friendly viewing glass platform. Those in Middelburg rest only meters from the successful provincial Zeeuwse Museum, yet are not viewable to the public. Both Brugge and Middelburg are are popular tourist spots and Aardenburg is trying to build on its touristic potential. If the graves become well known the attention they bring would be positive, and might help to uncover some of the mysteries, not just of these big city painted graves but of those in smaller cities also. With so little information available about grave frescoes the initiative to work together to preserve and bring attention to these graves would be worthwhile.

\section{CONSERVATION}

\subsection{Rationale}

The first aim in recommended conservation will not be to immediately interfere with the painted surface, but to stabilise it. For this reason treatments must be done with caution, aiming to first stabilize, stop, or reverse the harm done by finding the root causes and how they are acting in each circumstance. Often deterioration is not isolated, with different causes potentiating each other (More, Mora and Philippot, 1984). The current state of each location will be commented on in order to explain why fragments require individual attentions and why the solution in Brugge, although hugely informative, will not necessarily suffice for all locations. Recommendations for stopping deterioration will be very basic, and price estimates do not include travel time, possible accommodation costs, or for unexpected delays or findings.

\subsection{Brugge}

Despite having so many graves in Brugge's Saint Salvator Church, the four medieval frescoed graves have been the ones exposed, researched and protected. Especially in comparison with the complete four-sided grave in Middelburg, the graves in Brugge appear to have extremely good cohesion between layers and little flaking. The walls are structurally sound, which is important since the graves are very close together and at times share the same walls, or walls that rely on one another for support. The environment beneath the glass is protected. There is a monitored air flow to stabilize the environment and monitor humidity and dampness levels, as well as light reaching the paintings. Being such a large and frequently visited church, it was also necessary to guard the paintings against the tourist visitations. The graves will be cleaned once a year, which is often. For some wall paintings cleaning only a few times in a century is recommended (Nisbeth, 1980). Therefore the frescoes in Brugge should be watched carefully for deterioration or rapid colour loss. The cost for yearly checks such as this would be at least $€ 1300$ annually. The cleanings in Brugge are one example of how different areas could co-operate to more effectively preserve the grave frescoes. Due to the similar material composition and age of the graves, if Aardenburg, Middelburg or other localities with such graves take into account how successful the repetitive cleaning process in Brugge is, it may save time, money, and help to find an appropriate method of preservation more quickly. For now, Brugge is an example to other locations.

\subsection{Aardenburg}

In Aardenburg, the twenty graves are difficult to comment on in terms of future conservation. Half of the graves are reburied, and the other half has been left exposed since the 1950s. Both these options can cause deterioration. In the case of the reburied graves, the deterioration will not be known unless an investigation is instigated. It would be tragic to unwittingly lose this heritage while it is out of sight and photographic documentation has been lost.

It is understood that the exposed graves have suffered discolouration from the church heating system and additional heating for concerts (Haakma, 1994). Photographic evidence from the 1950's has been lost so no direct comparison is possible. Excessive changes in heat, either higher or lower, are dangerous for paintings, even harsh seasonal weather can have too much sudden fluctuation in temperature. The heating system in Aardenburg was inefficient, and the gas heating released only a radiant heat and its soot was too easily absorbed into the bedacryl varnish that covered the painted layer (Haakma, 1994). Almost two decades ago in 1994, Haakma recommended that the first course of action for the Aardenburg frescoes should be to remove the discoloured bedacryl varnish that was added in the initial 1950's conservation. This advice is still yet to be acted upon. If action were to be taken today, a fresh research should be undertaken to measure aspects like discolouration, the relationship between the paint layer and the plaster, the danger of removing the varnish layer.

A large curtain was installed between the main body of the church where the graves are, and the apse where masses are 
held in an attempt to regulate heat change, but this is not enough. The graves have been raised above the ground so they are exposed from all sides rather than being surrounded by earth which is more consistent in temperature, but it is still possible to control the airflow to the graves. The best option would be to control the air flow of the entire church, since the room is used by worshippers to get to the front of the church for masses anyway. Geveke Technical Solutions in The Netherlands has estimated that an air-regulation fan (fan code: 904 SS L Enhanced BC VAV TB EC) would cost $€ 11,000$ to buy, $€ 2,500$ for installation and commission, and $€ 1350$ per year for maintenance. This is a very expensive undertaking, but will regulate the environment of the entire church. In this case, glass layers covering the tops of the graves need not be made air-tight, but must stop access to the grave space.

Although Aardenburg is a small, rather inaccessible town to visit, it is an important historical Roman city and the graves are a crucial aspect of the church and city's history. It is worthwhile investing in keeping the graves from deteriorating. Local academics have put much effort into establishing an interesting Archaeological Museum, historical city walks and more. Although the recommended changes are expensive, relocating the graves would not be advisable. Few other locations would be able to house ten graves. Starting a new investigation into the condition of these graves would cost approximately $€ 6,500$ with annual check-ups costing around $€ 3,200$ per year.

\subsection{Middelburg}

In Middelburg the condition of the painted surfaces is not consistent for all nine fragments, and a general conservation investigation needs to be completed for all. To begin with the first grave of four paintings: despite being protected by a glass layer the general condition of the painted surface is poor. There is much flaking, a large proportion of the surface is completely lost and has been filled with cement. There are large gaps where both mortar and plaster are missing showing a lack of cohesion between all layers, not just the paint and lower foundations, though this dominates. Air from the surrounding damp crypt has access to the grave via six small pipes along the long sides of the grave. However, this is not the original grave location; it is inaccessible to the public, and detrimental to the survival of the graves. As a result a new display area would be ideal. Investigation could be undertaken for them to be housed in other Middelburg locations such as the Provincial Museum, or another monumental building like the Nieuwe Kerk, both of which are popular visitor locations and only metres away from the Abdijplein crypt.

The second group of fragments is generally in much better condition than the first, although almost an entire half of one is lost. They are kept in an airtight display case which is fortunate due to the damp air in the larger room housing six of the fragments. There is evidence of past treatments, because of the shiny transparent surface. Damage can be seen in a spider's hole, a cracking in the more recent concrete casing, and salt blooming. Overall, the first painting, [Fig. 5] has much better cohesion between all painting layers, while [Fig. 6] is half lost, and with much flaking. Since these two frescoes are likely traceable to the Sluis St Peter's Church excavation, it could be a good idea to relocate the graves to the Sluis Museum that currently houses a number of frescoes from the same church excavation. Sluis is still part of the area monitored by SCEZ.

The third group of frescoes is unfortunately located in an empty corner of a passageway in the same crypt between the Abdij market entrance, and an elevator. It is subject to much foot-traffic, artificial lighting, dust, and they are grouped with a lot of other storage material. One wall is facing upwards, another has its painted surface half hidden behind the first as it faces into the room, and the third is completely facing the wall. Its pictorial content is to this day unknown. Considering dust, debris and paper had to be swept from the painted surface to allow for documentation, these also need urgent relocation. Without more information about their origins, a new location in Middelburg would be best. Including company commission, the initial treatments, checks and relocations of these graves would cost over $€ 9,000$ before adding necessary equipment, transportation machinery, or the cost of additional actions recommended during the Conservation analysis.

\section{CONCLUSION}

Each of these cities house medieval grave frescoes in different states of preservation, which are in need of different attentions. Despite these differences, visual similarities and common patterns in material use and building methods make them a unique product of the region's cultural heritage. There are still many questions that can better be answered by treating them as parts of a tradition. This paper has only supplied preventative means of conservation rather than methods that interfere with the painted surface, but stabilization is most necessary and this alone will cost over $€ 30,000$ plus the cost of yearly check-ups in all three locations. The purpose of this paper was to highlight the unique situation in small regions of The Netherlands and Belgium, in the hope that it will contribute to additional interest and research. In the meantime, the conservation recommended will aid the stabilization of the painted surface through a stabilization of the surrounding area. The main concerns being airflow, air quality, temperature change, light, and surface protection. From here onwards, there should be co-operation to help the survival of all these graves. Each city location requires a unique strategic effort for stabilization and preservation. Communication between cities will help to create consistency where possible by using the experiences of others to aid decision making in the future. In Brugge action has just been taken with the help of Raakvlak the local Archaeology Services. Aardenburg, Middelburg and other locations must encourage SCEZ and Dutch Archaeology Services that now is the time to copy and learn and preserve these cultural treasures.

\section{REFERENCES}

Beck, James, Daley, Michael. Art Restoration: The culture, the business, and the scandal. J. Murray (Ed) London 1993.

Devliegher, Luc. “De Sint Bavokerk te Aardenburg.” Bulletin KNOB 6.9 (1956): 96-215. Print. 
Dezutter, W.P., Dr. "Beschilderde Middeleeuwse Grafkelders in Zeeuwsch-Vlaanderen: Een kunsthistorische en archeologische studie". Ph.D. dissertation, Rijksuniversiteit Gent, Academiejaar 1969-1970.

Haakma Wagenaar, Willem. De Beschilderde Graven in Aardenburg. 1994. Report made accessible by Rijksdienst voor het Cultureel Erfgoed in Amersfoort.

Hutsebaut, Jan, Etiennen Dhont, and Layla Aerts.Verstild versteend verleden: monumenten in Knokke-Heist, Damme, Maldegem, Sint-Laurens en Sluis. S.1.: [s.n.], 2010. Print.

Information boards St Salvator Church, 2011, Archaeologisch onderzoek: Sint-Salvatorskerkhof, Februari-Mei 2011: Geschiedenis, methode, vondsten en resultaten van het onderzoek, Raakvlak \& Stad Brugge, Brugge, Belgium.

Mora, Paolo, Laura Mora, and Paul Philippot. Conservation of wall paintings. London: Butterworths, 1984. Print.

Nisbeth, Ake. "Deterioration and Restoration of some Swedish Mural Paintings."Conservation within historic buildings: preprints of the contributions to the IIC Vienna Congress, 7-13 September 1980. London: The International Institute for Conservation of Historic and Artistic Works, 1980. 126-129. Print.

Renaud, J.G.N..Onderzoekingen in de Sint Bavo te Aardenburg . S.1.: [s.n.], 1956. Print.

S'Jacobs, .E. "Beschilderde Middeleeuwse grafkelders te Aardenburg en Sluis." Bulletin van de Kon. Ned. Oudheidkundige Bond 8.4 (1955): 25-151. Print

\section{ACKNOWLEDGEMENTS}

This paper is a short version of a much more extensive study completed with the support and supervision of two people: Dr Helle Hochscheid on behalf of the Roosevelt Academy in Middelburg, and Drs Robert van Dierenonck on behalf of Stichting Cultureel Erfgoed Zeeland. Much co-operation with workers from SCEZ, and the Royal Institute for Cultural Heritage in Brussels was required to access sources for this study. Arco Willebordse personally showed me the graves in the Aardenburg St Bavo Church, as did workers at the Brugge Sint Salvator Church. Wietse Gelderloos from Geveke Technical Solutions provided a free estimation of buying, installing and maintaining an air regulator in Aardenburg's Sint Bavo Church. 